\title{
Pelayanan Pembuatan Akta Kelahiran Di Kabupaten Subang
}

\author{
${ }^{1}$ Wawan Setiawan Abdillah, ${ }^{2}$ Puji Fitriani Abdullah
}

${ }^{1}$ UIN Sunan Gunung Djati Bandung, Indonesia; wansabdillah.80@uinsgd.ac.id ${ }^{2}$ UIN Sunan Gunung Djati Bandung, Indonesia; pujifitriania@gmail.com

\begin{abstract}
According to the data gained by researchers from the Department of Population and Civil Registration in Subang, there are still the number of children aged 0 to 18 years who do not owna Birth Certificate. In 2018, the Subang Population and Civil Registry Service set a target of 85\%, where children in Subang Ages 0 to 18 years must own a Birth Certificate. However, there are lots of obstacles to realizing this target, both from service and the community. The research method used in this study is qualitative approach. In this study, researchers used a descriptive research type so that it would be described how effective the service of making Birth Certificates for Children aged 0 to 18 years in the Population and Civil Registry Office of Subang. In order to get data and information, The techniques that the researchers did are through observation and interviews. The results of the research in the field show that the effectiveness of birth certificate making services in the context of fulfilling the identity of children aged 0 to 18 years in Subang in terms of service is very optimal but there are obstacles from the community.
\end{abstract}

Keywords: Effectiveness, Civil Service, Local Government, Decentralization.

\section{Pendahuluan}

Kelahiran seorang anak merupakan sebuah modal bangsa yang harus dilindungi oleh negara. Hal tersebut tercermin dari pengesahan Convention On The Rights Of The Child ( Konvensi Tentang Hak Anak) yang diatur dalam Keputusan Presiden Nomor 36 Tahun 1990 bahwa setiap anak yang lahir mempunyai hak-hak yang harus dipenuhi. Beberapa hak yang harus didapatkan oleh anak tersebut diantaranya adalah hak untuk memiliki kehidupan yang layak, mendapatkan kualitas pendidikan yang prima, serta hak untuk memperoleh nama dan identitas (Akta Kelahiran).

Secara realitas di lapangan, jika melihat pada sebuah dokumen laporan Dinas Kependudukan dan Pencatatan Sipil Kabupaten Subang, maka hal tersebut dinilai belum cukup efektif dan memuaskan, terutama pada layanan pembuatan akta kelahiran. Sebagaimana data mengenai target dan realisasi pembuatan Akta Kelahiran Kabupaten Subang dari beberapa tahun, berikut ini:

Tabel 1.1

Capaian Kinerja Dalam Meningkatkan Kepemilikan Akta Kelahiran Anak Usia 0 sampai 18 Tahun

\begin{tabular}{|l|l|l|l|}
\hline TAHUN & KONDISI (\%) & $\begin{array}{l}\text { TARGET } \\
(\%)\end{array}$ & REALISASI (\%) \\
\hline 2014 & 44 & 100 & 49,88 \\
\hline 2015 & 49,88 & 100 & 62,81 \\
\hline 2016 & 62,81 & 75 & 57,13 \\
\hline 2017 & 57,13 & 75 & 65,13 \\
\hline
\end{tabular}

Sumber: LAKIP Dinas Kependudukan dan Pencatatan Sipil Kabupaten Subang 
Berdasarkan data diatas, dapat dilihat bahwa terjadi fluktuasi antara penurunan dan peningkatan angka dan persentase. Namun, dalam kurun waktu empat tahun, yaitu dari tahun 2014 sampai tahun 2017, menunjukkan ketidaktercapaian target yang telah direncanakan dan ditentukan oleh Pemerintahan Kabupaten Subang. Dapat dilihat di tahun 2014, yaitu bahwa capaian kinerja belum mencapai target yang diharapkan. Ketika target yang ditetapkan dalam kewajiban membuat akta kelahiran bagi anak usia 0 sampai 18 tahun sebesar $100 \%$, namun pada secara realitas hanya mampu mencapai $49,88 \%$ anak yang berkesempatan membuat akta kelahiran. Di tahun berikutnya, yaitu 2015, target $100 \%$ masih belum tercapai, karena dalam kenyataan di lapangan, anak yang membuat akta kelahiran mampu mencapai $62,81 \%$. Selanjutnya juga di tahun 2016 terjadi penurunan target, yaitu 75\%, namun tetap saja pada realitanya hanya mendapat $57,13 \%$. Selanjutnya, meskipun terjadi peningkatan persentase di tahun 2017, namun tetap saja target belum bisa tercapai $75 \%$.

Dalam hal ini yaitu untuk mengukur efektivitas pelayanan publik, Siagian (1996) menjabarkannya dalam tiga konsep pemberian pelayanan, sebagai berikut:

1. Waktu

Maksud dari aspel waktu disini, yaitu bahwa ketepatan waktu dan kecepatan waktu dari pelayanan yang diberikan. Hanya saja penggunaan ukuran tentang tepat tidaknya atau cepat tidaknya pelayanan yang diberikan berbeda dari satu orang kepada orang lain.

\section{Kecermatan}

Aspek kecermatan disini yaitu bahwa tingkat ketelitian dari seorang pelayan kepada pengguna layanan. Pengguna layanan akan cenderung memberikan nilai yang tidak terlalu tinggi kepada seorang pelayan, apabila terjadi banyak kesalahan dalam proses pelayanan, meskipun diberikan dalam waktu yang singkat.

\section{Gaya Pelayanan}

Aspek Gaya pelayanan ini mengandung makna bahwa cara dan kebiasaan seorang pelayan dalam memberikan jasa kepada pengguna layanan. Bisa saja pengguna layanan merasa tidak sesuai dengan gaya pelanggan yang diberikan oleh pemberi pelayanan.

Dalam rangka untuk melindungi anak-anak daerah dari jenis kejahatan perdagangan dan eksploitasi manusia di bawah umur, maka Pemerintahan Kabupaten Subang dalam hal ini Disdukcpil menargetkan 85\% bahwa di tahun 2018 anak berusia 0 sampai 18 harus memiliki akta kelahiran, sebagaimana yang telah ditentukan dan diayur dalam lingkup nasional. Dalam rangka untuk mewujudkan target tersebut, maka salah satu cara dan langkah yang hisa dilakukan adalah dengan mempermudah setiap wali orang tua memperoleh akta kelahiran anaknya dengan memberikan pelayanan secara gratis. Program tersebut dilakukan karena pemerintah ingin agar setiap anak di Indonesia bisa mendapatkan hak kependudukannya sebagai warga negara Indonesia secara penuh. Oleh karena itu, anak-anak menjadi individu yang berkualitas guna mendapatkan generasi Indonesia yang lebih baik. Adapun indikasi permasalahan yang penulis temukan adalah sebagai berikut:

1. Masih ditemukan keterlambatan dalam pembutan Akta kelahiran di Dinas Kependudukan dan Pencatatan Sipil Kabupaten Subang.

2. Dalam proses pembuatan Akta Kelahiran masih ada petugas yang melakukan kesalahan dalam pemindahan data dan kurang teliti dalam memasukan data-data yaitu salah dalam mencantumkan nama anak, nama orang tua, tempat lahir, tanggal lahir dan tahun lahir ke dalam register dan kutipan akta kelahiran. Hal tersebut mengakibatkan banyak masyarakat yang datang kembali untuk memperbaiki Akta Kelahiran. 
3. Petugas yang melakukan pelayanan pada kantor Dinas Kependudukan dan Pencatatan Sipil Kabupaten Subang belum diberi pelatihan dan diintruksikan serta diberi pengarahan oleh sebab itu banyaknya petugas pelayanan kurang sopan, ramah, saling menghargai dan menghormati.

Maka dengan demikian, berdasarkan pada analisis latar belakang tersebut, maka penelitian ini memiliki tujuan yaitu untuk menganalisis bagaimana efektivitas pelayanan pembuatan akta kelahiran dalam rangka pemenuhan identitas anak usia 0 sampai 18 tahun di dinas kependudukan dan pencatatan sipil Kabupaten Subang dan apa saja kendala yang dihadapinya.

\section{Metode Penelitian}

Metode penelitian dalam penelitian ini adalah tipe penelitian deskriptif dengan pendekatan kualitatif. Dalam penelitian kualitatif ini, peneliti bermaksud ingin memahami fenomena tentang apa yang dialami oleh subjek penelitian misalnya perilaku, persepsi, motivasi, tindakan baik secara holistik dengan cara dekripsi dalam bentuk katakata dan bahasa, pada suatu konteks khusus yang alamiah dan dengan memanfaatkan berbagai metode alamiah. Adapun tipe penelitian ini yang digunakan adalah metode deskriptif, karena penelitian ini diarahkan untuk memberikan gejala-gejala, faktafakta, atau kejadian-kejadian secara sistematis dan akurat mengenai sifat-sifat populasi maupun daerah tertentu.

Dalam hal sumber data yang digunakan, peneliti melakukanya denga dua cara yaitu data primer dan data sekunder, dengan beberapa teknik pengumpulan data, yaitu observasi, dan wawancara mendalam. Sedangkan Teknik analisis yang digunakan dalam penelitian ini adalah analisis data model Strous dan Corbin (Grounded Theory) terdiri dari tiga jenis pencodean utama yaitu pengodean terbuka (Opening Coding), pengodean berporos (Axial Coding), dan pengodean selektif (Selective Coding).

\section{Hasil dan Pembahasan}

\section{A. Efektivitas Pelayanan Pembuatan Akta Kelahiran}

\section{Aspek Waktu}

Terlepas dari penilaian dari satu orang ke orang lain, faktor waktu dapat dijadikan sebagai salah satu ukuran efektivitas pelayanan. Untuk mengukur aspek ketepatan waktu ini digunakan lima indikator sebagai berikut:

a. Kesesuaian antara waktu penyelesaian pembuatan akta kelahiran dengan standar waktu yang telah ditetapkan.

Standar waktu yang harus diterapkan sesuai dengan Standar Operasional Prosedur (SOP). Didalam SOP di jelaskan mengenai kelompok dan jenis pelayanan apa saja yang dapat diberikan, persyaratan apa saja yang harus dipenuhi dalam mengajukan permohonan pembuatan akta kelahiran, dicantumkan juga lamanya waktu penerbitan Akta Kelahiran,dijelaskan prosedur/tahapan pelaksanaan kegiatan dan pelaporan yang dilakukan oleh Kepala Dinas Kependudukan dan Pencatatan Sipil setiap bulannya.

Adapun waktu yang yang diperlukan untuk mendaftar pembuatan akta kelahiran adalah 1 hari kerja apabila syarat-syarat sudah beres terpenuhi. Berdasarkan wawancara secara khusus dengan kepala bidang pencatatan sipil bahwa sesuai dengan Undang-Undang No. 23 Tahun 2016 tentang Administrasi Kependudukan dinyatakan bahwa waktu yang telah ditetapkan 
untuk penerbitan dokumen kependudukan yang salah satunya penerbitan Akta kelahiran yaitu 14 (empat belas) hari kerja, akan tetapi pada kasus-kasus tertentu masih ada keterlambatan dalam proses penerbitan. Namun di Tahun 2018 Pemerintah Dinas Kependudukan dan Pencatatan Sipil menetapkan target 85\% Anak di Subang harus memiliki Akta Kelahiran untuk mewujudkan target tersebut berusaha sekuat tenaga untuk memperbaiki pelayanan pembuatan akta kelahiran dengan cara penerbitan akta kelahiran dari 14 hari kerja menjadi 7 hari kerja apabila semua persyaratannya lengkap, pernyataannya sebagai berikut:

"Sangat sesuai malahan kita memperbaiki 14 hari kerja menjadi 7 hari kerja dalam membuat Akta Kelahiran, itu diperbaiki karena masyarakat yang mengeluh terlalu lama pembuatan akta kelahiran. Lalu kita juga telah kerjasama dengan istansi lain seperti halnya Sekolah Dasar. Disekolah Dasar disyaratkan jika anak yang mau masuk Sekolah Dasar harus ada akta kelahiran”. (Wawancara tanggal 11 Februari 2019).

Dari pernyataan diatas dapat kita ketahui bahwa Dinas Kependudukan dan Pencatatan Sipil Kabupaten Subang di tahun 2018 untuk mewujudkan target 85\% tersebut telah memperbaiki pelayanan pembuatan akta kelahiran dengan cara melakukan perbaikan dari yang 14 hari kerja pembuatan Akta Kelahiran menjadi 7 hari kerja apabila berkas peryaratan yang dimiliki masyarakat lengkap dan jelas. Selain itu Dinas Kependudukan dan pencatatan Kabupaten Subang bekerjasama dengan Sekolah Dasar agar kepemilikan Akta Kelahiran Anak di tahun 2018 meningkat.

b. Verifikasi dan Validasi Berkas oleh Petugas sesuai dengan waktu yang telah ditentukan

Indikator yang kedua yaitu verifikasi dan validasi berkas oleh petugas sesuai waktu yang telah ditentukan, merupakan hal yang penting karena dalam verifikasi dan validasi berkas persyaratan memerlukan ketelitian dan kemampuan, agar dapat melakukan verifikasi dan validasi berkas dengan cepat tanpa melakukan kesalahan. Apabila terjadi kesalahan akan menghambat terhadap proses selanjutnya yang akan menimbulkan keterlambatan karena harus melakukan konfirmasi kepada penduduk yang memohon pembuatan akta kelahiran. Untuk itu pegawai ditugaskan untuk verifikasi dan validasi berkas persyaratan harus melakukan pekerjaannya sesuai dengan waktu yang telah ditentukan. Didalam SOP memverifikasi dan validasi berkas membutuhkan waktu satu hari. Adapun berkas-berkas persyaratan yang dibutuhkan untuk membuat Akta Kelahiran antara lain:

1. Surat keterangan lahir dari Rumah Sakit/ RS Bersalin/ Puskesmas/ Poliklinik/ Desa/ Dokter Praktek Swasta/ Bidan Praktek Swasta atau dari Pilot/ Nahkoda pesawat terbang atau kapal Laut;

2. Foto Copy kartu Keluarga;

3. Foto copy KTP kedua orang tua;

4. Foto copy akta nikah yang dilegalisir

5. Foto copy KTP 2 orang saksi;

6. Mengisi formulir F-2.01

7. Foto copy paspor/KITAS/KITAP bagi WNA;

8. Dokumen yang sudah diterjemahkan dan dilegalisir oleh kedutaan yang bersangkutan 
Selanjutnya peneliti melakukan wawancara kepada staf pelayanan pembuatan Akta Kelahiran karena yang lebih mengetahui mengenai verifikasi dan validasi persyaratan Akta Kelahiran adalah staf pelayanan pembuatan Akta Kelahiran, pernyataannya sebagai berikut:

"Dalam Pelaksanaan verifikasi dan validasi berkas persyaratan akta kelahiran sudah dilaksankan dengan baik sesuai dengan waktu yang ditentukan”. (Wawancara tanggal 11 Februari 2019).

Sehingga dapat disimpulkan oleh peneliti mengenai indikator diatas dapat dipaparkan bahwa pelaksanaan verifikasi dan validasi berkas persyaratan Akta Kelahiran telah dilaksanakan dengan baik sesuai waktu yang telah ditentukan hanya pada waktu-waktu tertentu ketika pemohon yang akan membuat Akta Kelahiran terlalu banyak melebihi yang rutin dilaksanakan, maka penyelesaiannya melebihi waktu yang telah ditetapkan dan masih dalam tahap yang bisa ditolelir. Bagi pegawai yang belum bisa melaksanakan verifikasi dan validasi berkas persyaratan secara tepat waktu, harus dilakukan pembinaan melalui pendidikan dan pelatihan sehingga pegawai tersebut mempunyai keahlian dan tidak melakukan kesalahan dalam pekerjaannya sehingga bisa diselesaikan tepat pada waktunya.

c. Entry data dan penerbitan/percetakan Akta Kelahiran

Didalam SOP entry data untuk Akta Kelahiran memerlukan waktu 10 menit dan untuk percetakan Akta Kelahiran memerlukan waktu 5 menit. Kemudian penulis melakukan wawancara dengan Staf pelayanan pembuatan Akta Kelahiran, pernyataannya sebagai berikut:

"Entry data dan penerbitan/percetakan Akta Kelahiran sesuai dengan waktu yang telah ditentukan. Tetapi terkadang pelaksanaan entry datadan penerbitan/percetakan Akta Kelahiran jaringannya kadang-kadang ada gangguan sehingga memerlukan perbaikan yang mengakibatkan entry data penerbitan/pencetakan Akta Kelahiran mengalami sedikit keterlambatan dalam prosesnya." (Wawancara tanggal 11 Februari 2019).

Menurut peneliti seharusnya jaringan internet dapat dipelihara secara rutin supaya tidak terjadi gangguan jaringan. Dengan demikian pekerjaan entry data dan penerbitan/percetakan akta kelahiran dapat selesi tepat pada waktu ditentukan. Hasil kesimpulan peneliti mengenai indikator diatas, memaparkan bahwa entry data dan penerbitan/pencetakan Akta Kelahiran menjadi terlambat karena adanya gangguan jaringan internet, itupun terjadi kadang-kadang dan dapat diperbaiki sehingga masih dalam batas yang wajar. Untuk itu penyampaian Akta Kelahiran kepada masyarakat sesuai waktu yang telah ditentukan, maka perlu pegawai atau petugas yang menangani pekerjaan tersebut ditugaskan untuk lembur.

d. Paraf dan penandatanganan Akta Kelahiran sesuai dengan waktu yang telah ditentukan

Indikator yang keempat adalah paraf dan penandatanganan Akta Kelahiran sesuai dengan waktu yang telah ditentukan. Di dalam SOP paraf dan penandatanganan memerlukan waktu 1 hari oleh Kepala Dinas.

Berdasarkan hasil wawancara dengan Kasi Kelahiran mengenai paraf dan penandatanganan Akta Kelahiran, pernyataannya sebagai berikut:

"Sesuai dengan waktu yang telah ditentukan yang berarti sudah terlaksana dengan baik. Tetapi terkadang masih ada yang terlambat dikarenakan Kepala Dinas yang berwenang memberikan tanda tangan tersebut melaksanakan tugas ke luar kota. (Wawancara tanggal 11 Februari 2019).

Hasil kesimpulan peneliti mengenai indikator paraf dan penandatanganan Akta Kelahiran sesuai dengan waktu yang telah ditentukan, hal ini menggambarkan bahwa paraf dan penandatangan Akta Kelahiran oleh Kepala Dinas telah dapat dilaksanakan dengan baik. 
Hanya pada waktu tertentu saja masih terlambat karena Kepala Dinas yang berwenang untuk memberikan paraf dan tanda tangan Akta Kelahiran tidak ada di Kantor karena tugas luar. Apabila jaraknya masih bisa terjangkau maka dokumen yang harus ditanda-tangan dibawa ketempat pegawai yang berwenang tersebut, agar sampai ke penduduk dengan tepat waktu.

e. Penyerahan Akta Kelahiran Kepada Pemohon/Penduduk Sesuai Dengan Waktu Yang Telah Ditentukan

Indikator yang kelima adalah penyerahan Akta Kelahiran kepada pemohon/penduduk sesuai dengan waktu yang telah ditentukan. Berdasarkan informasi yang peneliti peroleh bahwa penyerahan Akta Kelahiran kepada pemohon/penduduk telah sesuai dengan waktu yang ditentukan, yang berarti sudah terlaksana dengan baik tetapi terkadang terlambat satu sampai dengan tiga hari karena adanya data yang harus dikonfirmasi kepada pemohon. Akan tetapi pemohon terlambat untuk mengkonfirmasi data tersebut. Selain itu juga dari pihak pemohon/penduduk terlambat untuk mengambil Akta Kelahiran tersebut karena mereka sibuk atau merasa kepentingan tersebut tidak mendesak. Untuk memastikan kebenaran informasi peneliti melakukan wawancara khusus dengan Kepala Bidang Pencatatan Sipil, pernyataanya sebagai berikut:

"Masih banyak akta kelahiran yang belum diambil oleh pemohon/ penduduk. Dokumen Akta Kelahiran tersebut masih tersimpan dengan baik, apabila nanti diambil sudah siap untuk diberikan kepada pemohon tersebut." (Wawancara tanggal 11 Februari 2019).

Kesimpulan peneliti mengenai indikator diatas menggambarkan bahwa penyerahan Akta Kelahiran kepada pemohon/penduduk telah sesuai dengan waktu yang telah ditentukan, yang berarti dapat dilaksanakan dengan baik. Satu hal pada kasus tertentu, karena terlambat untuk konfirmasi data dan adanya pemohon/penduduk yang terlambat mengambil akta kelahiran. Berdasarkan dari hasil wawancara pada dimensi ketepatan waktu ternyata diketahui bahwa dimensi faktor waktu ini berada pada kategori tinggi. Dengan demikian hal ini memberikan kecenderungan bahwa indikator-indikator pada dimensi waktu telah terpenuhi dengan baik.

\section{Aspek Kecermatan}

Untuk mengukur aspek kecermatan ini digunakan lima indikator sebagai berikut:

\section{a. Penyampaian Informasi Tentang Pembuatan Akta Kelahiran}

Indikator pertama yaitu penyampaian informasi tentang pembuatan Akta Kelahiran. Penyampaian informasi ini sangat penting agar masyarakat mengetahui tata cara pembuataan Akta Kelahiran. Dinas kependudukan dan pencatatan Sipil Kabupaten Subang menyampaikan Informasi melaui berbagai cara seperti di WEB Disdukcapil Subang, ditempel didinding Kantor Dinas Kependukukan dan Pencatatan Sipil, dan melakukan penyampaian informasi secara langsung ke masyarakat. Hal ini diketahui ketika lanjutan wawancara penulis dengan Kepala Bidang Pencatatan Sipil, dengan pernyataannya sebagai berikut:

"Tindakan dari Disdukcapil Ketika Masyarakat bingung membuat Akta kelahiran kita menyampaikan informasi melalui sosialisasi ke Desa-Desa maupun Kecamatan. Sebab dengan adanya UUD 24 Tahun 2013 kita yang turun kelapangan bukan menunggu masyarakat disini. Sosialisasinya bisa dimana saja bisa di aula desa bahkan dipasarpun kita bisa." (Wawancara tanggal 11 Februari 2019). 
Jadi dapat disimpulkan oleh peneliti mengenai indikator penyampaian informasi tentang pembuatan akta kelahiran sudah dapat dilaksanakan dengan baik walaupun masih ada pegawai yang pengetahuan dan kemampuan kurang mengenai Akta Kelahiran. Terhadap pegawai yang memiliki pengetahuan kurang perlu diikut sertakan dalam pelatihan, sehingga mereka mempunyai pengetahuan dan kemapuan yang baik.

b. Kelengkapan Persyaratan Dalam Pembuatan Akta Kelahiran

Indikator yang kedua yaitu kelengkapan persyaratan dalam pembuatan Akta Kelahiran. Memeriksa kelengkapan persyaratan harus mempunyai kecermatan dan ketelitian dari pegawai supaya proses pembuatan Akta Kelahiran sesuai pada waktunya. Menurut penelitian yang dilakukakan bahwa pegawai dalam memeriksa persyaratan Akta Kelahiran sudah cermat berarti mereka dalam memeriksa persyaratan pembuatan akta kelahiran sudah baik. Kemudian peneliti melakukan wawancara dengan staf pelayanan mengenai kecermatan dalam memeriksa persyaratan dalam pembuatan Akta Kelahiran, pernyataannya sebagai berikut:

"Kalo dalam memeriksa kelengkapan persyaratan yang paling tidak lengkap yaitu surat nikah, kebanyakan tidak punya surat nikah. Kan neng biasanya orang sini nikahnya nikah lebe atau nikah secara agama, kalo tidak lengkap terpaksa kita tidak bisa layani”. (Wawancara tanggal 11 Februari 2019).

Dapat peneliti simpulkan mengenai indikator kelengkapan persyaratan dalam pembuatan akta kelahiran sudah dapat dilaksanakan dengan baik itu terbukti ketika memeriksa berkas yang tidak lengkap.

c. Pengecekan Data Kependudukan Menurut Database Kependudukan

Indikator yang ketiga yaitu pengecekan data kependudukan antara yang dimiliki penduduk dengan database kependudukan. Dalam pengecekan data kependudukan dibutuhkan kecermatan dan ketelitian dari pegawai karna apabila salah maka akan terjadi kesalahan dalam pembuatan Akta Kelahiran. Berdasarkan wawancara dengan Kepala Bidang Pencatatan Sipil diperoleh penjelasan mengenai kecermatan pengecekan data kependudukan antara yang dimiliki penduduk dengan database kependudukan, pernyataannya sebagai berikut:

"Human Error pasti ada karena tingkat pekerjaan banyak. Tetapi apabila datanya sudah ada dalam database itu tidak mungkin salah. Tinggal kita masukan persyaratan apabila diklik tidak ada surat nikah otomatis yang ada nama ibunya saja. Disini kita sudah sistem online”. (Wawancara tanggal 11 Februari 2019).

Sehingga dapat peneliti simpulkan mengenai indikator pengecekan data kependudukan antara yang dimiliki penduduk dengan database kependudukan sudah dapat dilaksanakan dengan baik karena jika data telah masuk ke database kependudukan tidak akan salah, walaupun masih ada data penduduk yang tidak sama antara yang dimiliki penduduk dengan database kependudukan bisa langsung diperbaiki sehingga datanya sama.

d. Entry data penerbitan/pencetakan Akta Kelahiran

Indikator yang keempat yaitu entry data penerbitan/pencetakan Akta Kelahiran. Dalam memasukan data-data dibutuhkan kecermatan dari petugas untuk meminimalisir kesalahan. Entry data sangat penting karna apabila salah dalam memasukan data maka akan berakibat kepada salahnya pencetakan Akta Kelahiran. 
Dalam memasukan data ke komputer pegawai tak jarang melakukan kesalahan seperti memasukan nama anak, nama orangtua, tempat lahir tanggal lahir baik itu murni kesalahan pegawai itu sendiri ataupun bisa saja dari kesalahan pemohon dalam menulis data-datanya. Berdasarkan wawancara yang peneliti lakukan dengan Staf Pelayanan Pembuatan Akta Kelahiran mengenai kesalahan dalam melakukan entry data penerbitan/pencetakan Akta Kelahiran, pernyataannya sebagai berikut:

“Kesalahan pasti ada. Tapi masyarakat balik lagi”. (Wawancara tanggal 11 Februari 2019).

Jadi kesimpukan peneliti mengenai indikator entry data dan penerbitan/pencetakan Akta Kelahiran telah dapat dilaksanakan dengan baik, hanya masih ada kesalahan dalam entry datanya sehingga setelah dicetak data tidak sama dengan data yang diinginkan oleh penduduk kemudian bisa langsung diperbaiki dan dicetak ulang.

\section{e. Verifikasi Dan Validasi Persyaratan Akta Kelahiran}

Indikator kelima yaitu verifikasi dan validasi persyaratan Akta Kelahiran. Dalam hal ini verifikasi dan validasi berarti menyangkut tingkat kebenaran dari persyaratan yang diberikan oleh pemohon pembuat Akta Kelahiran. Peneliti melakukan wawancara kepada Staf Pelayanan Pembuatan Akta Kelahiran mengenai kecermatan dalam melakukan verifikasi dan validasi persyaratan pembuatan Akta Kelahiran, pernyataannya sebagi berikut:

"Verifikasi dan validasi persyaratan pembuatan akta kelahiran telah dilaksanakan dengan baik namun ya pernah neng pernah melakukan kesalahankesalahan namanya juga manusia ditambah kita disini pekerjaannyanya banyak”. (Wawancara tanggal 11 Februari 2019).

Peneliti menyimpulkan mengenai indikator verifikasi dan validasi persyaratan pembuatan Akta Kelahiran dapat dilakukan dengan baik walaupun pernah terjadi kesalahan tetapi masih bisa dimaklumi karena pekerjaan mereka yang sangat banyak lalu apabila ada kesalahan memerlukan konfirmasi kepada pemohon/penduduk dengan langsung melakukan komunikasi melalui telepon untuk kesamaan datanya.

Berdasarkan dari hasil wawancara pada dimensi kecermatan ternyata diketahui bahwa kecermatan ini berada pada kategori tinggi. Dengan demikian hal ini memberikan kecenderungan bahwa indikator-indikator pada dimensi kecermatan telah terpenuhi dengan baik. Hal ini berarti menurut hasil wawancara Efektivitas Pelayanan Pembuatan Akta Kelahiran Anak oleh Dinas Kependudukan dan Pencatatan Sipil Kabupaten Subang tahun 2018 telah terlaksana dengan baik berdasarkan dimensi kecermatan.

\section{Aspek Gaya Pelayanan} berikut:

Untuk mengukur gaya pemberian pelayanan digunakan emapat indikator sebagai

a. Percaya Diri Dalam Menyampaikan Hal-Hal Yang Berkaitan Dengan Pembuatan Akta Kelahian

Berdasarkan wawancara yang peneliti lakukan dengan dua staf pelayanan pembuatan Akta Kelahhiran mengenai percaya diri, pertama pernyataannya sebagai berikut:

"Kalo teteh sih neng percaya diri soalnya udah lama juga kerja di Didisdukcapil Subang ya jadi sudah terbiasa menghadapi masyarakat yang membuat Akta Kelahiran”. (Wawancara tanggal 11 Februari 2019). 
Dapat disimpulkan oleh peneliti mengenai indikator percaya diri terbagi menjadi dua yaitu: pertama, staf pelayanan mempunyai rasa kepercayaan diri yang baik sehingga dalam melakukan pelayanan pembuatan Akta Kelahiran bisa meyakinkan pemohon/penduduk. Kedua, Staf Pelayanan yang menyatakan cukup baik mereka merasa masih aga canggung dengan melakukan pelayanan yang harus ditingkatkan pengetahuan dan kemampuan.

b. Ramah Dan Sopan Dalam Memberikan Pelayanan Pembuatan Akta Kelahiran

Berdasarkan temuan peneliti dilapangan mengenai ramah dan sopan bahwa staf pelayanan pembuatan Akta kelahiran mereka melakukan pelayanan selalu bersikap ramah dan sopan kepada masyarakat. Tetapi disisi lain yang peneliti liat ada staf pelayanan tapi bukan pegawai pembuatan Akta Kelahiran melakukan pelayanan kurang ramah dan sopan terlihat oleh peneliti ada staf pelayanan yang memarahi masyarakat dikarenakan permasalahan tertentu. Selain itu ditemukan banyaknya antrian yang sangat panjang untuk mendaftar identitas penduduk oleh sebab itu emosi baik itu dari masyarakat sendiri atau staf menjadi meluap.

Untuk membuktikan temuan penulis dalam penelitian maka penulis melakukan wawancara dengan kasi inovasi pelayanan terkait ramah dan sopan, pernyataannya sebagai berikut:

\section{"Petugas Kurang Ramah dan Sopan itu merupakan hambatan dari Disduk sendiri karena seperti yang kami tahu petugas yang berada di loket pendaftaran kebanyakan lulusan SMA yang belum diberikan Diklat dan pasti ada anggapan dari masyarakat kurangnya kesopanan dari petugas biasanya masyarakat memberikan kritik dan sarannya lewat kotak saran atapun melalui website yang telah kami sediakan ". (Wawancara tanggal 11 Februari 2019).}

Hasil wawancara mengenai indikator ramah dan sopan, dapat digambarkan bahwa mayoritas staf pelayanan dalam melakukan pelayanan selalu bersikap ramah dan sopan sehingga masyarakat yang mengurus pembuatan akta kelahiran merasa nyaman, dihargai dan dihormati. Kemudian staf yang dinyatakan kurang ramah dan sopan merupakan pegawai pelayanan dibidang lain bukan di bidang pelayanan Akta Kelahiran seharusnya mereka berusaha untuk bisa ramah dan sopan dalam melakukan pelayanan kepada masyarakat/penduduk tetapi masih bisa dimaklumi karena yang masyarakat yang mendaftar Administrasi Kependudukan sangat banyak dengan watak yang berbeda-beda jadi masih bisa dimaklumi apabila berselisih paham atau pendapat dan yang harus dimiliki oleh staf pelayanan ataupun pegawai pelayanan adalah ekstra sabar.

c. Empati Dengan Memahami Apa Yang Dirasakan Oleh Masyarakat Yang Membuat Akta Kelahiran

Indikator yang ketiga yaitu empati. Empati merupakan keadaan dimana pikiran dan perasaan sama dengan orang lain serta mau turut untuk memahami apa yang sedang dirasakan orang tersebut. Berdasarkan hasil wawancara dengan staf pelayanan Akta Kelahiran menganai empati, pernyataannya sebagai berikut:

"Kalo teteh mah orangnya karunyaan neng, kalo ada masyarakat yang kurang lengkap persyaratannya teteh kasih tau sebisa teteh harus bagaimananya karena yang membuat akta kelahiran tidak hanya masyarakat yang dekat ke kota saja, masyarakat dari kampung juga dateng, lalu kalo dulu yang telat membuat akta kelahiran ada sanksinya neng sekarang tidak, da kita kasihan”. (Wawancara tanggal 11 Februari 2019). 
Dapat kita simpulkan mengenai indikator empati sudah efektif, hal ini menunjukan bahwa staf pelayanan maupun pegawai pembuatan Akta Kelahiran mempunyai rasa empati yang baik yaitu mempunyai kemauan untuk melakukan pendekatan dan berusaha untuk mengetahui keinginan dan kebutuhan masyarakat merasa diperhatikan dengan baik.

d. Adil

Indikator yang keempat yaitu adil. Adil adalah suatu sikap yang tidak memihak atau sama rata, tidak ada yang lebih dan tidak ada yang kurang, tidak ada pilih kasih dan masih banyak persepsi yang lainnya. Berdasarkan hasil wawancara dengan pegawai pelayanan mengenai indikator adil terdapat beberapa jawaban, pernyataannya sebagai berikut:

Pertama, diungkapkan oleh Kasi Identitas Penduduk, pernyataannya sebagai berikut:

"Adil. Soalnyaan disini kita sistemnya mengambil antrian jadi yang duluan antri ya dia yang dipanggil duluan". (Wawancara tanggal 11 Februari 2019).

Kesimpulan yang peneliti dapatkan mengenai indikator adil ini memberi makna bahwa pegawai dalam melakukan pelayanan kepada masyarakat berusaha untuk bertidak adil atau tidak membeda-bedakan golongan, ras, jabatan, keluarga dan teman. Kemudian pegawai yang menyatakan cukup adil, mereka memberikan pelayanan secara khusus terhadap keluarga dalam melakukan pelayana pembuatan akta kelahiran dan juga membantu pemohon akta kelahiran yang sangat membutuhkan sekali sehingga didahulukan.

Berdasarkan hasil dari indikatorindikator pada dimensi gaya pemberian pelayanan ternyata diketahui bahwa dimensi gaya pemberian pelayanan ini berada pada kategori baik. Dengan demikian hal tersebut menunjukan bahwa indikator-indikator pada dimensi gaya pemberian pelayanan telah dapat terlaksana dengan baik. Hal ini berarti menurut penulis efektivitas pelayanan pembuatan Akta Kelahiran oleh Dinas Kependudukan dan Pencataan Sipil Kabupaten Subang telah terlaksana dengan baik berdasarkan dimensi gaya pemberian pelayanan.

\section{B. Kendala Dalam Pelayanan Pembuatan Akta Kelahiran}

Berdasarkan uraian diatas mengenai efektivitas pelayanan pembuatan Akta Kelahiran dalam rangka pemenuhan identitas anak usia 0 sampai 18 tahun di Dinas Kependudukan dan Pencatatan Sipil Kabupaten Subang Tahun 2018 berdasarkan aspek-aspek teori efektivitas pelayanan dari Sondang P Siagian yaitu dimensi Ketepatan Waktu, Kecermatan, dan Gaya Pemberian Pelayanan sudah berjalan efektif dari segi pelayananan karena Dinas Kependudukan dan Pencatatan Sipil Kabupaten Subang mempunyai target 85\% kepemilikan Akta Kelahiran sehingga pelayanan pembuatan Akta Kelahiran di perbaiki. Namun setelah dilakukan penelitian terdapat beberapa faktor penghambat dalam pembuatan Akta Kelahiran yaitu dari segi masyarakat sehingga dapat menghambat target 85\% kepemilikan Akta Kelahiran Anak di tahun 2018 yaitu:

Pertama, Kesadaran masyarakat yang masih rendah belum mengerti dan memahami tentang pentingnya memiliki akta kelahiran. Akta kelahiran ini sangat penting untuk identitas seorang anak yang merupakan bukti otentik bagi seorang anak, sehingga ada perlakuan hukum bagi anak tersebut. Kurangnya kesadaran dari masyarakat juga bisa dipengaruhi oleh Budaya terkadang masyarakat masih memegang budaya bahwa pemberian nama anak itu harus nunggu 40 hari. Padahal idealnya seorang ibu pada saat kehamilan harus diupayakan membuat nama 
untuk anaknya. Jadi sebelum persalinan harus sudah mempersiapkan berkas untuk pembuatan Akta Kelahiran, begitu anaknya lahir segera membuat Akta Kelahiran.

Dengan adanya kurang kesadaran dari masyarakat maka ketepatan waktu untuk mencapai target sebesar $85 \%$ anak disubang harus sudah memiliki akta kelahiran menjadi terhambat. Berdasarkan wawancara dengan Kepala Bidang Pencatatan Sipil, pernyataanya sebagai berikut:

"Hambatan untuk mencapai target 85\% kepemilikan Akta Kelahiran Anak terhambatarna kurangnya kesadaran masyarakat. Jadi dari pihak disduknya yang harus kesana ke masyarakat langsung”. (Wawancara tanggal 11 Februari 2019).

Kedua, Masih adanya penduduk yang melakukan nikah siri, otomatis tidak mempunyai surat nikah. Walaupun nikah siri ini sah menurut agama tetapi tidak sah menurut Negara, maka dalam akta kelahiran hanya ditulis anak dari seorang Ibu. Namun pada kenyataannya penduduk yang membuat akta kelahiran tidak mau hanya ditulis anak dari seorang Ibu, nama bapak anak tersebut juga ingin ditulis dalam akta kelahiran. Petugas registrasi tidak bisa mengabulkan keinginan peduduk tersebut karena tidak ada akta nikah. Maka dari pada itu ada yang menunda pembuatan akta kelahiran karena tidak dicantumkan nama Bapak dalam akta kelahiran.

Ketiga, Penduduk atau masyarakat tidak mempunyai biaya untuk ongkos mengurus akta kelahiran, karena jarak dari rumah ketempat pelayanan jauh dalam hal ini ke Kantor Dinas Kependudukan dan Pencatatan Sipil Kabupaten Subang. Kemudian dilihat dari dimensi kecermatan, setelah peneliti melakukan wawancara dengan Kepala Bidang Pencatatan Sipil masih terdapat beberapa masalah mengenai kesalahan dalam penulisan Akta Kelahiran seperti nama anak, nama orang tua, tempat tanggal lahir. Kesalahan tersebut bisa dikarenakan kesalahan dari petugas langsung ataupun dari masyarakat. Berikut ini adalah hasil wawancara peneliti dengan Staf Akta Kelahiran mengenai kecermatan, pernyataannya sebagai berikut:

"Pasti ada kesalahan dalam pembuatan Akta Kelahiran. Tapi masyarakat balik lagi . Kebanyakan yang mendaftarkan itu neng orang desa, nah terjadi ketidak sinkronan antara orang desa dengan masyarakat. sehingga terjadilah kesalahan”. (Wawancara tanggal 11 Februari 2019).

Dari kedua pernyataan diatas, dapat peneliti artikan bahwa kendala dalam dimensi kecermatan itu itu terdiri dari dua faktor yaitu dari pegawai itu sendiri dan dari masyarakat. Dari pegawai karena tingkat pekerjaan mereka yang banyak jadi kurang fokus dalam memasukan data-data pemohon. Lalu dari masyarakat yang malas ke Disdukcapil langsung menitipkan persyaratannya kepada Bidan, orang desa bahkan kepada calo dari situ muncul ketidak sinkronan antara masyarakat dengan petugas. Kemudian dari dimensi gaya pemberian pelayanan terdapat kendalakendala antara lain Kendala pertama dari gaya pemberian pelayanan yaitu belum diadakan pelatihan atau training menjadi customer service yang baik. Pihak Dinas Kependudukan dan Pencatatan Sipil pernah mendapatkan kritik dari pelanggan yang disimpan dikotak saran terkait keramahan dan kesopanan petugas. Berdasarkan wawancara dengan Kasi Inovasi Pelayanan terdapat pemahaman menganai kendala dalam gaya pemberian pelayanan, pernyataannya sebagai berikut:

"Pihak Disdukcapil sendiri kurang anggaran untuk melaksanakan pelatihan atau diklat kepada customer servise. Dari pemerintah sendiri anggaran yang masuk ke Disduk itu sangat sedikit dibandingkan dengan anggaran pendidikan, kesehatan jauh banget. Kita itu mungkin dapet sepersekian, kalo untuk pendidikan kalau tidak salah diatas $10 \%$ anggarannya termasuk untuk kesehatan juga. Kalo Disduk sendiri hanya dapat 0,0 sekian padahal 
apa yang kita keluarkan dokumen itu kan sangat penting, ketika pemerintah memberikan anggaran untuk bantuan bpjs persyaratannya kan harus memiliki KK, KTP, Akta Kelahiran tapi memang tidak berpihaklah ke kami”. (Wawancara tanggal 11 Februari 2019).

Dapat kita simpulkan bahwa untuk memperbaiki gaya pemberian pelayanan harus dilakukan pelatihan atau diklat menjadi customer service yang baik namun kendalanya di anggaran. Tetapi peneliti sendiri memakluminya karena yang mendaftar pelayanan semakin siang semakin ramai, ditambah banyak calo yang berdatangan dan tak jarang sering berselisih paham dengan calo. Namun jika gaya pemberian pelayanan dapat diperbaiki lagi maka masyarakat akan betah dalam melakukan pelayanan Administrasi Kependudukan.

\section{Simpulan}

Efektivitas Pelayanan Pembuatan Akta Kelahiran Anak Usia 0 Sampai 18 Tahun di Dinas Kependudukan dan Pencatatan Sipil Kabupaten Subang berdasarkan tiga dimensi efektivitas pelayanan pada umumnya berjalan baik. Pada dimensi waktu, kesesuaian antara penyelesaian pembuatan akta kelahiran dengan standar waktu yang telah ditetapkan pada umumnya telah dapat dicapai dengan baik. Pada dimensi kecermatan, pada umumnya kecermatan pembuatan akta kelahiran mulai dari penyampaian informasi, pengecekan kelengkapan persyaratan, pengecekan data kependudukan, verifikasi dan validasi persyaratan serta entry data penerbitan/percetakan akta kelahiran berada pada kategori tinggi. Pada dimensi gaya pemberian pelayanan, pegawai pelayanan pembuatan Akta Kelahiran telah memberikan pelayanan yang baik dalam pembuatan akta kelahiran.

Sedangkan dalam kaitannya dengan kendala dalam pelayanan pembuatan akta kelahiran dalam rangka pemenuhan identitas anak usia 0 sampai 18 tahun di Kabupaten Subang dari sisi pelayanan sudah efektif karena di tahun 2018 ada target $85 \%$ kepemilikan akta kelahiran anak usia 0 sampai 18 tahun oleh sebab itu dari segi pelayanan di tahun 2018 sudah diperbaiki namun ada kendala lain dari masyarakat. Terdapat tiga kendala yaitu kurangnya kesadaran masyarakat, banyaknya masyarakat yang menikah siri sehingga di dalam Akta Kelahiran dicantumkan nama ibunya saja, Penduduk atau masyarakat tidak mempunyai biaya untuk ongkos mengurus akta kelahiran karena jarak dari rumah ketempat pelayanan jauh dalam hal ini ke Kantor Dinas Kependudukan dan Pencatatan Sipil Kabupaten Subang.

\section{Referensi}

Affifudin., Saebani, B.A. (2012). Metodelogi Penelitian Kualitataif. Bandung: Pustaka Setia.

Anggara, S. 2015. Metode Penelitian Administrasi. Bandung: CV Pustaka Setia

Danim, S. (2004). Motivasi Kepemimpinan dan Efektivitas Kelompok. Jakarta: PT Rineka Cipta.

Djamil, N. M. (2008). Anak Bukan Untuk Dihukum.Jakarta Barat: Sinar Grafika.

Gibson. (1990). Organisasi Prilaku, struktur dan proses.Jakarta: Erlangga.

Handayaningrat, S.(1985). Sistem Birokrasi Pemerintah. Jakarta: CV. Haji Mas Agung.

Hidayat, A.dkk. (2017). Reformasi Administrasi Teori Dan Aplikasi. Bandung: Fisip Unpas Press.

Islamy, M..I. (1997). Prinsip-prinsip Perumusan Kebijakan Negara. Jakarta: Bumi Aksara. 
Kontjaningrat. (1999).Metode-Metode Penelitian Masyarakat. Jakarta: Cirameda.

Kurniawan, A. (2005). Transformasi Pelayanan Publik. Yogyakarta: Pembaruan.

Mahmudi. (2005). Manajemen Kinerja Sektor Publik. Yogyakarta: UPP AMP YKPN.

Moenir. (2006). Manajemen Umum di Indonesia.Jakarta: PT Bumi Aksara.

Moleong, L.J. (2012). Metodelogi Penelitian Kualitatif. Bandung: PT Remaja Rosdakarya.

Nasehudin, T.S.,Gozali, N. (2012). Metode Penelitian Kualitatif. Bandung: Pustaka Setia.

Nawawi, H. (1998). Metode Penelitian Bidang Sosial. Yogyakarta: Gajah Mada University Press

Pasolong, H. (2013). Metode Penelitian Administrasi. Jakarta: Alfabeta.

Pasolong, H. (2014). Teori Administrasi Publik. Jakarta: Alfabeta.

Siagian, S.P. (1997). Organisasi, kepemimimpinan \& Prilaku Administrasi. Jakarta: CV. Haji Mas Agung.

Silalahi, U. (2018). Metode Penelitian Kuantitatif, Kualitataif, dan R\&D. Bandung Alfabeta.

Sinambela, L.P., dkk. (2006). Reformasi Pelayanan Publik. Jakarta: PT Bumi Aksara.

Siskamya, R. (2008). Implementasi Kebijakan Administrasi Kependudukan Pada Pemerintah Kota Bandung. Universitas Indonesia.

Soedadi. 1989. Organisasi dan Manajemen. Jakarta: Rineka Cipta.

Suryadi, H. (2009). Pengembangan Kinerja PelayananPublik. Bandung: PT Refika Aditama.

Syafiie, I.K. (2010). Ilmu Administrasi Publik. Jakarta: Rineka Cipta.

Triyanto. A. (2011). Pelaksanaan Sistem Administrasi Kependudukan Untuk Mencapai Kualitas Pelayanan Pembuatan KTP di Kabupaten Majalengka.

Wirawan. (2011). Evaluasi, Teori, Model, Aplikasi, dan Profesi. Jakarta: Rajawali Press.

Yulianto, R. (2011). Kualitas Pelayanan Administrasi Akta Kelahiran di Dinas Kependudukan Dan Catatan Sipil Kota Surabaya. 